Research Paper

\title{
Optimization and characterization of alkaline protease and carboxymethyl-cellulase produced by Bacillus pumillus grown on Ficus nitida wastes
}

\author{
Eman Zakaria Gomaa \\ Department of Biological and Geological Sciences, Faculty of Education, \\ Ain Shams University, Cairo, Egypt.
}

Submitted: April 16, 2011; Approved: September 10, 2012

\begin{abstract}
The potentiality of 23 bacterial isolates to produce alkaline protease and carboxymethyl-cellulase (CMCase) on Ficus nitida wastes was investigated. Bacillus pumillus ATCC7061 was selected as the most potent bacterial strain for the production of both enzymes. It was found that the optimum production of protease and CMCase were recorded at $30{ }^{\circ} \mathrm{C}, 5 \%$ Ficus nitida leaves and incubation period of $72 \mathrm{~h}$. The best nitrogen sources for protease and CMCase production were yeast extract and casein, respectively. Also maximum protease and CMCase production were reported at $\mathrm{pH} 9$ and $\mathrm{pH}$ 10 , respectively. The enzymes possessed a good stability over a $\mathrm{pH}$ range of 8-10, expressed their maximum activities at $\mathrm{pH} 10$ and temperature range of $30-50{ }^{\circ} \mathrm{C}$, expressed their maximum activities at $50{ }^{\circ} \mathrm{C}$. Ions of $\mathrm{Hg}^{2+}, \mathrm{Fe} 2+$ and $\mathrm{Ag}^{+}$showed a stimulatory effect on protease activity and ions of $\mathrm{Fe}^{2+}, \mathrm{Mg}^{2+}, \mathrm{Ca}^{2+}, \mathrm{Cu}^{2+}$ and $\mathrm{Ag}^{+}$caused enhancement of CMCase activity. The enzymes were stable not only towards the nonionic surfactants like Triton X-100 and Tween 80 but also the strong anionic surfactant, SDS. Moreover, the enzymes were not significantly inhibited by EDTA or cystein. Concerning biotechnological applications, the enzymes retained (51-97\%) of their initial activities upon incubation in the presence of commercials detergents for $1 \mathrm{~h}$. The potential use of the produced enzymes in the degradation of human hair and cotton fabric samples were also assessed.
\end{abstract}

Key words: alkaliphillic, protease, carboxymethylcellulase, production, characterization.

\section{Introduction}

Soda lakes represent the major types of naturally occurring highly alkaline environments in which the indigenous microflora is subjected to number of extreme ecological pressures. They represent the most stable high $\mathrm{pH}$ environments on earth, where large amounts of carbonate minerals can generate $\mathrm{pH}$ values higher than 11.5 (Grant and Jones, 2000; Jones et al., 1998). Soda lakes are widely distributed throughout the world. One of those environmental niches which have not been studied in details is the Wadi El-Natrun soda lakes in northern Egypt. The features of Wadi El-Natrun area created an ecosystem which considers as rich source for isolation of different extremophiles, including alkaliphillic microorganisms.

Alkaliphiles are defined as organisms that grow optimally at alkaline $\mathrm{pH}$, with $\mathrm{pH}$ optima for growth being in excess of $\mathrm{pH} 8$ (usually between 9 and 10), and some being capable of growing at $\mathrm{pH}$ higher than 11 (Grant and Jones, 2000; Horikoshi, 1999). Alkaliphillic bacteria are reported to be a rich source of alkaline active enzymes e.g. amylase, protease, cellulase, xylanase, and other enzymes which have numerous applications in industrial processes (Horikoshi, 1991).

It has been established that there are three main types of enzymes found in the cellulase system that can degrade cellulose: exo- $\beta$-1,4-glucanase, EC 3.2.1.74; endo- $\beta-1,4-$ glucanase, EC 3.2.1.4 (Carboxymethyl cellulase) and $\beta$ glucosidase, EC 3.2.1.21. The endoglucanases act internally on the chain of cellulose cleaving $\beta$-linked bond liberating nonreducing ends, and exoglucanases remove cellobiose from this non-reducing end of cellulose chain. Finally, $\beta$-glucosidase completes the saccharification by 
splitting cellobiose and small cellooligosaccharides to glucose molecule (Silva et al., 2005). Potential applications of cellulases are in food, animal feed, textile, fuel, chemical industries, paper and pulp industry, waste management, medical/pharmaceutical industry, protoplast production, genetic engineering and pollution treatment (Tarek and Nagwa, 2007).

Alkaline protease has attracted worldwide attention in attempts to exploit their physiological and biotechnological applications e.g. in the detergents industry as additives, food processing, tanning, waste treatment, textile industry in the process of dehairing and leather processing and also have application in silver recovery from photographic plates. Furthermore, they are used in pharmaceuticals and medical diagnosis (Gupta et al., 2002; Joo et al., 2003).

Agricultural residues such as grasses, tree wastes and many other green plants whose disposal is considered as an environmental problem as they have been accumulating or used inefficiently due to the high cost of their utilization processes (Lee et al., 2006). Ficus nitida L. (Moraceace) is a widely cultivated ornamental tree in Egypt. It yields a vast amount of wastes yearly either from fallen leaves or as a result of continuous shaping and pruning. Ficus wastes are highly nutritious, containing considerable amounts of celluloses, proteins and trace elements (Kitajima and Kimizuka,1998).

The present study aimed at studying the optimum conditions for production of alkaline protease and CMCase enzymes by Bacillus pumilus ATCC7061, isolated from Wadi El-Natrun soda lakes, grown on low cost substrate (Ficus nitida wastes). Furthermore, characterization and application of the produced enzymes were also studied.

\section{Materials and Methods}

\section{Isolation of alkaliphillic bacteria}

Four different soil samples were collected from different localities of Wadi El-Nartoun in northern Egypt. These were Dawood, El-Bida, El-Hamra and Bani Salama. Isolation of alkaliphillic bacteria was carried out using alkaline agar medium of Horikoshi (1990). It contained 1\% glucose, $0.5 \%$ peptone, $0.5 \%$ yeast extract, $0.1 \% \mathrm{KH}_{2} \mathrm{PO}_{4}$, $0.02 \% \mathrm{MgSO}_{4} .7 \mathrm{H}_{2} \mathrm{O}, 1 \% \mathrm{Na}_{2} \mathrm{CO}_{3}$ and $1.5 \%$ agar, $\mathrm{pH} 10.5$. Aliquots $(100 \mu \mathrm{L})$ of different dilutions of soil suspensions samples were plated and incubated at $30^{\circ} \mathrm{C}$ for three days. According to the morphological characteristics of different colonies on agar plates, inocula from these grown colonies were transferred into replicates of slants containing the same specific media. Purified isolates were maintained on agar slants of the same medium at $4{ }^{\circ} \mathrm{C}$ and was subcultured at monthly intervals.

\section{Screening of protease and CMCase enzymes production}

Purified colonies were transferred to skim milk agar plates to be screened for protease production. The medium contained peptone (0.1\%), $\mathrm{NaCl}(0.5 \%)$, agar $(2.0 \%)$, and skim milk (10\%) (Ellaiah et al., 2002a). The appearance of clear zones around the colonies as a result of casein hydrolysis was taken as an indication of protease production. The strains showing proteolytic activities were screened for $\mathrm{CMCase}$ production. A preliminary qualitative analysis for cellulolytic activity was conducted by using Congo red dye method of Ariffin et al. (2006). The bacteria were grown on $\mathrm{CMC}$ agar containing $(\mathrm{g} / \mathrm{L}): \mathrm{KH}_{2} \mathrm{PO}_{4} 1.0, \mathrm{MgSO}_{4} .7 \mathrm{H}_{2} \mathrm{O}$ $0.5, \mathrm{NaCl} 0.5, \mathrm{FeSO}_{4} .7 \mathrm{H}_{2} \mathrm{O} 0.01, \mathrm{MnSO}_{4} \cdot \mathrm{H}_{2} \mathrm{O}$ 0.01, $\mathrm{NH}_{4} \mathrm{NO}_{3}$ 0.3, CMC 10.0, Agar 20.0. The formation of a clear zone of hydrolysis indicated cellulose degradation. The strain showed the highest production of protease and CMCase enzymes was selected for further experimental studies.

\section{Strain identification}

Strain Alk9 which was the highest protease and CMCase producer was identified by $16 \mathrm{~S}$ rDNA sequence. Comparisons of the sequence between different species suggest the degree to which they are related to each other. This was done by constructing phylogenetic tree using neighbour-joining (N-J) method (Ariffin et al., 2006).

\section{Production of alkaline protease and CMCase enzymes}

Production of protease by Bacillus pumilus ATCC7061 was carried out in a medium containing the following $(\mathrm{g} / \mathrm{L})$ : glucose.1.0, yeast extract, $0.5, \mathrm{CaCl}_{2} .0 .1$, $\mathrm{K}_{2} \mathrm{HPO}_{4}, 0.5$ and $\mathrm{MgSO}_{4}, 0.1$ (Ul-Qadar et al., 2009). The peptone content of the original medium was replaced with washed and ground dry leaves of Ficus nitida in a concentration of $10 \mathrm{~g} / \mathrm{L}$. Production of CMCase was carried out in a medium containing the following $(\mathrm{g} / \mathrm{L})$ : $\mathrm{KH}_{2} \mathrm{PO}_{4} 1.0$, $\mathrm{K}_{2} \mathrm{HPO}_{4} \quad 1.145, \quad \mathrm{MgSO}_{4} .7 \mathrm{H}_{2} \mathrm{O} \quad 0.4, \quad\left(\mathrm{NH}_{4}\right)_{2} \mathrm{SO}_{4} \quad 5.0$ $\mathrm{CaCl}_{2} .2 \mathrm{H}_{2} \mathrm{O} 0.05$ and $\mathrm{FeSO}_{4} .7 \mathrm{H}_{2} \mathrm{O} 0.0012$ (Ariffin et al., 2006). Ficus nitida leaves at concentration of $10 \mathrm{~g} / \mathrm{L}$ were used as carbon source instead of CMC.

Erlenmeyer conical flasks of $500 \mathrm{~mL}$ capacity containing $100 \mathrm{~mL}$ of the modified media adjusted at $\mathrm{pH} 10$ were inoculated with $1.0 \mathrm{~mL}$ spore suspension of the strain (adjusted to $1.0 \mathrm{OD}_{600}$ ) and incubated at $30{ }^{\circ} \mathrm{C}$ in a rotary incubator $(150 \mathrm{rpm})$ for $72 \mathrm{~h}$. The culture fluids were centrifuged at $10000 \mathrm{xg}$ for $20 \mathrm{~min}$ and the clear cell free supernatants were regarded as crude enzyme supernatants.

\section{Protease and CMCase activities assay}

Proteases activity was determined by a slightly modified method of Yang et al. (2000). The reaction mixture containing $1 \mathrm{~mL}$ of $1.0 \%$ casein solution in $0.05 \mathrm{M}$ Glycine- $\mathrm{NaOH}$ buffer having $\mathrm{pH} 10$ and $1 \mathrm{~mL}$ of a given enzyme solution were incubated at $40{ }^{\circ} \mathrm{C}$ for $30 \mathrm{~min}$ and the reaction was then stopped with $3 \mathrm{~mL}$ of $10 \%$ trichloroacetic acid (TCA), mixed well and the non-hydrolyzed casein was precipitated by centrifugation at $10,000 \mathrm{xg}$ for $10 \mathrm{~min}$. The 
supernatant was utilized for protease determination according to the method established by Lowry et al. (1951) using a standard curve prepared with tyrosine. One unit of alkaline protease activity was expressed as the amount of the enzyme that released $1 \mu$ mole of tyrosine per minute under the assay conditions. CMCase activity was assayed using a modified method described by Wood and Bhat (1998) with some modifications. Briefly, $0.2 \mathrm{~mL}$ of culture filtrate was added to $1.8 \mathrm{~mL}$ of $1 \%$ CMC prepared in Glycine- $\mathrm{NaOH}$ buffer ( $\mathrm{pH} 10)$ in a test tube and incubated at $40{ }^{\circ} \mathrm{C}$ for $30 \mathrm{~min}$. The reaction was terminated by adding $3.0 \mathrm{~mL}$ of dinitrosalicylic acid (DNS) reagent and by subsequently placing the reagent tubes in water bath at $100{ }^{\circ} \mathrm{C}$ for $15 \mathrm{~min}$. One milliliter of Rochelle salt solution (40\%) was then added to stabilize the color. The absorbance was recorded at $575 \mathrm{~nm}$ against the blank (of $0.05 \mathrm{M}$ sodium citrate buffer). One unit of CMCase activity was expressed as $1 \mu$ mole of glucose liberated per ml enzyme per minute.

\section{Biomass yield}

Bacterial biomass was determined by measuring the absorbance at $600 \mathrm{~nm}$.

\section{Factors affecting the enzymes production}

\section{$\mathrm{pH}$ and temperature}

In order to investigate the influence of $\mathrm{pH}$ on enzymes production, Bacillus pumilus ATCC7061 was grown at different $\mathrm{pH}$ values (7.0-11.0). Similarly, the influence of temperature was investigated by varying the incubation temperature $\left(20-40{ }^{\circ} \mathrm{C}\right)$ at optimum $\mathrm{pH}$, keeping the other parameters also constant.

\section{Ficus nitida leaves concentration}

Different concentrations (0.5-6\%) of Ficus nitida leaves were added separately to the production media of protease and CMCase enzymes.

\section{Nitrogen sources}

Yeast extract and ammonium sulphate (control) in case of protease and CMCase production media, respectively were replaced at equivalent nitrogen concentration by different nitrogen sources. Five inorganic nitrogen sources (ammonium chloride, ammonium nitrate, ammonium sulphate, potassium nitrate and sodium nitrate) and five organic nitrogen sources (ammonium acetate, casein, peptone, urea and yeast extract) were separately supplemented to the medium. The same cultural conditions as previously stated were adopted.

\section{Salts}

Different $\mathrm{K}_{2} \mathrm{HPO}_{4}$ concentrations (0, 0.25, 0.5, 1.0 and $1.5 \mathrm{~g} / \mathrm{L}$ ) were added separately in protease production medium. On the other hand, CMCase production medium contained $(1.0+1.14) \mathrm{g} / \mathrm{L}$ of $\mathrm{KH}_{2} \mathrm{PO}_{4}+\mathrm{K}_{2} \mathrm{HPO}_{4}$ was replaced by different concentrations $(0+0,0.5+0.64$,
$1.5+1.64$ and 2.0:2.14 g/L). These concentrations were added separately to the modified medium. Also, different concentrations of $\mathrm{MgSO}_{4}(0.0-0.8 \mathrm{~g} / \mathrm{L})$ were added separately to the modified protease and CMCase production media to determine the most promising concentration for enzymes production.

\section{Incubation period}

After optimizing all the nutritional and environmental factors described above, the protease and CMCase production media were cultivated for 5 days. During cultivation, a sample of culture broth was withdrawn periodically (every $24 \mathrm{~h}$ ) for enzymes activities determination as mentioned before.

\section{Characterization of protease and CMCase}

\section{Effect of $\mathrm{pH}$ on enzymes activity and stability}

Effect of $\mathrm{pH}$ on protease and CMCase activities were determined by assaying the enzyme activity as described above at different $\mathrm{pH}$ values ranging from 7.0 to 12.0 , using the following buffer systems: $0.05 \mathrm{M}$ of phosphate $(\mathrm{pH} 7)$, tris- $\mathrm{HCl}(\mathrm{pH} 8-9)$ and glycine- $\mathrm{NaOH}(\mathrm{pH} \mathrm{10-12).} \mathrm{The} \mathrm{pH}$ stability of the enzymes was investigated in the same $\mathrm{pH}$ range and incubated at $40{ }^{\circ} \mathrm{C}$ for $1 \mathrm{~h}$. Afterwards, aliquots of the mixtures were taken to measure the residual protease activity (\%) with respect to the control, under standard assay conditions.

\section{Effect of temperature on enzymes activity and stability}

Effect of temperature on enzymes activities were determined by incubating the reaction mixture at optimum $\mathrm{pH}$ value under different temperature ranging from $\left(30-80^{\circ} \mathrm{C}\right)$. In order to determine the thermostability of the enzymes, experiments were conducted by measuring the residual activity after incubation in the same temperatures range for 60 min under standard assay conditions.

Effect of various metals ions, surfactants and inhibitors on enzymes activity

Effect of metal ions, surfactants and inhibitors on the activity of protease and CMCase enzymes were determined in the presence of metal ions $\left(\mathrm{K}^{+}, \mathrm{Na}^{+}, \mathrm{Ag}^{+}, \mathrm{Ca}^{2+}, \mathrm{Cu}^{2+}\right.$, $\mathrm{Fe}^{2+}, \mathrm{Hg}^{2+}, \mathrm{Mg}^{2+}$, and $\mathrm{Zn}^{2+}$, final concentration of $5 \mathrm{mM}$ ), SDS, Triton X-100 and Tween 80 (1\%), Ethylenediamine tetraacetic acid (EDTA) and L-cystein $(5 \mathrm{~mm})$. The enzymes were pre-incubated with the above-mentioned chemicals for $1 \mathrm{~h}$ at $50{ }^{\circ} \mathrm{C}$, afterwards, the relative activity $(\%)$ was calculated with respect to the control where the reaction was carried out in the absence of any additive under the optimum assay conditions (Lo et al., 2001).

\section{Compatibility with commercial detergents}

Detergents available in the national market, such as Ariel, Persil, Tide and X-tra were used. To simulate washing conditions, these detergents were diluted in distilled 
water up to a final concentration of $7.0 \mathrm{mg} / \mathrm{mL}$. The solutions were boiled for $10 \mathrm{~min}$ for the inactivation of their enzymes contents already present and cooled. Protease and CMCase enzymes of $B$. pumilus ATCC7061 were then added to the detergents solution in a ratio of $(1: 1)$ and incubated for $1 \mathrm{~h}$ at $50^{\circ} \mathrm{C}$. The residual activities were then determined. The enzymes activities of control samples (without any detergent) were taken as 100\% (George et al., 2001).

\section{Application of protease and CMCase enzymes}

\section{Degradation of human hair}

Untreated black human hair (1 g) was suspended in $50 \mathrm{~mL}$ protease of Bacillus pumilus and the reaction mixture was incubated at $40{ }^{\circ} \mathrm{C}$ for $1 \mathrm{~h}$. The reaction mixture was cooled and filtered to stop the enzymatic reaction. Human hair was dried and weighed to determine the loss of weight.

\section{Tests on cotton fabric}

Cotton fabric sample $(1.5 \mathrm{~g})$ was incubated at room temperature with $50 \mathrm{~mL}$ CMCase of Bacillus pumilus ATCC 7061. After 6 days, the samples were washed in water, dried, and weighed to determine the loss of weight.

\section{Statistical analysis}

Results are presented as mean value \pm standard deviation (SD). The Microsoft Excel 2003 and SAS 9.1.3 statistical program were used for data analysis.

\section{Results and Discussion}

\section{Isolation and screening of alkaliphillic bacteria}

Twenty three alkaliphillic bacteria were isolated from four different soil samples collected from different localities of Wadi El-Nartoun in northern Egypt. The isolates exhibited diversity towards gram's reaction, colony and cell morphology including 11 Gram positive rods, 7 Gram positive cocci, 3 Gram negative rods and 2 Gram negative cocci (data not shown). After preliminary investigation of these alkaliphillic bacteria to produce protease and CMCase enzymes, only $12(52 \%)$ isolates were found to be protease producers as detected by clear zones of casein hydrolysis around colonies in skim-milk agar plates. Among these bacterial strains seven strains exhibited evident clear zones around the colonies on CMC agar plates and were recorded as cellulase producers.

It was found that Alk9 isolate yielded the highest protease and CMCase enzymes productivity. In order to identify the strain, the nucleotide sequence of the $16 \mathrm{~S}$ rDNA of the strain was determined. Phylogenetic tree was constructed by the neighbour-joining (N-J) method based on the 16S rDNA sequences. The results revealed that strain Alk9 exhibited high level of 16S rDNA similarity (99\%) with Bacillus pumilus ATCC7061.

\section{Factors affecting protease and CMCase production}

$p H$

The results presented in Figure 1 show that production of protease and CMCase by Bacillus pumilus ATCC7061 were increased with increasing $\mathrm{pH}$ of medium towards alkaline range from neutrality. Maximum enzymes production was at $\mathrm{pH} 9(21.45 \mathrm{U} / \mathrm{mL})$ and $10(15.86 \mathrm{U} / \mathrm{mL})$ for protease and CMCase, respectively. This suggested that the bacterial strain was alkaliphillic in nature and optimum $\mathrm{pH}$ range between 9 and 10 for growth and enzymes production is common feature among alkaliphillic organisms (Denizci et al., 2004; Johnvesly and Naik, 2001). It is well known that $\mathrm{pH}$ of the culture medium affects the availability of certain metabolic ions and permeability of bacterial cell membranes, which in turn support the cell growth and enzymes production (Ellaiah et al., 2002b).

\section{Temperature}

Growth temperature is another critical parameter that needs to be controlled. The incubation temperature is usually determined by considering the sources from which the organisms have been isolated. Maximum production of protease and CMCase enzymes were recorded at $30{ }^{\circ} \mathrm{C}$ (Figure 2). At higher temperature, both enzymes production decreased because the enzymes begin to suffer thermal inactivation.

\section{Concentration of Ficus nitida leaves}

On studying the ability of Bacillus pumilus ATCC7061 to utilize Ficus nitida wastes and/or produce alkaline protease and CMCase enzymes, it was found that $5 \%(\mathrm{w} / \mathrm{v})$ was optimum for both enzymes production (Figure 3). Further increasing in the concentration had an adverse effect on enzymes production. Ficus nitida wastes were used in the present study as a sole source of carbon for CMCase production and as a nitrogen source for protease production. Chemical analysis of Ficus nitida leaves used

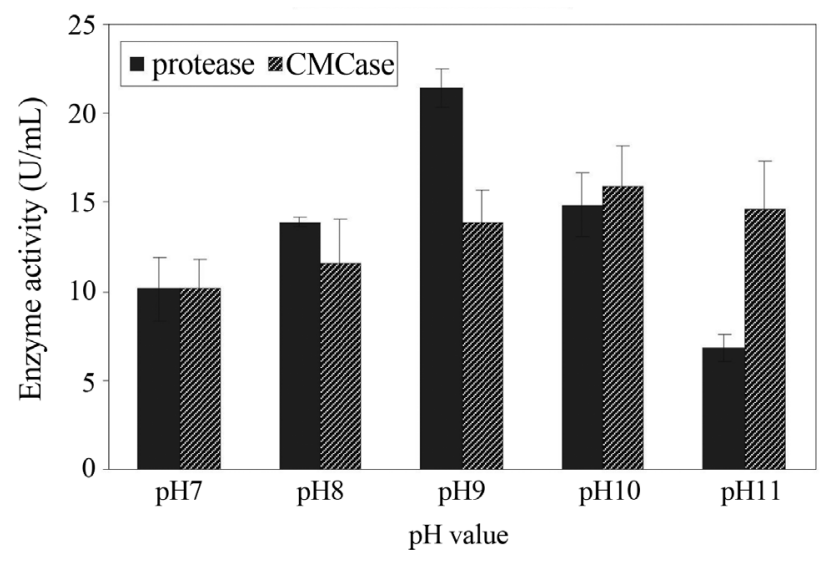

Figure 1 - Effect of different $\mathrm{pH}$ values on the production of protease and CMCase by Bacillus pumilus ATCC 7061. Results are means of three independent determinations. Bars correspond to standard deviation. 


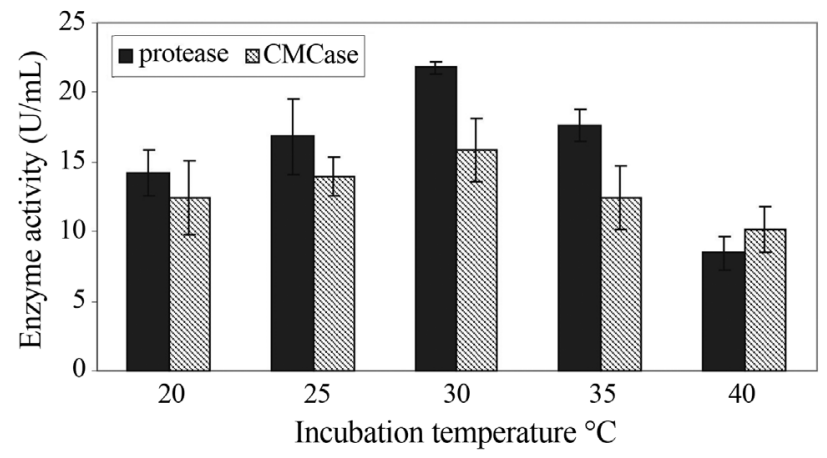

Figure 2 - Effect of incubation temperature on the production of protease and CMCase by Bacillus pumilus ATCC 7061. Results are means of three independent determinations. Bars correspond to standard deviation.

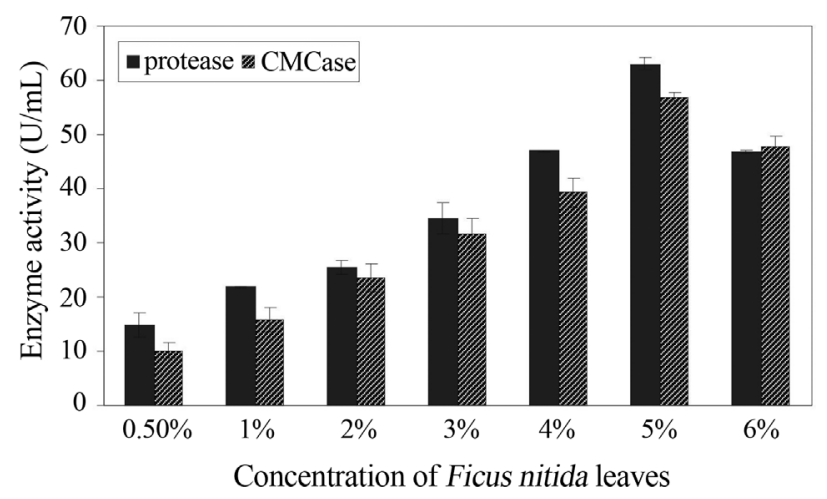

Figure 3 - Effect of different concentrations of Ficus nitida leaves on the production of protease and CMCase by Bacillus pumilus ATCC 7061. Results are means of three independent determinations. Bars correspond to standard deviation.

in the fermentation medium showed it contained $33.8 \%$ cellulose and $6.31 \%$ protein. These results showed the efficacy of applying these agricultural wastes as plentiful and cheap media for biomass production that will benefit the utilization of these abundant agricultural wastes and to produce many important substances with economic importance. In this regard, Nizamudeen and Bajaj (2009) previously replaced CMC of the cellulase production medium with alternative substrates such as wheat straw, wheat bran, saw dust or filter paper as alternative approaches for production of low cost enzymes from bacteria.

\section{Nitrogen sources}

Nitrogen source has got profound influence on enzyme production as it is the ultimate precursor for protein biosynthesis. Besides, the nitrogen source can also affect the $\mathrm{pH}$ of the medium, which in turn may influence the activity and stability of the enzyme (Nizamudeen and Bajaj, 2009). On an equivalent nitrogen basis, yeast extract and ammonium sulphate in the original media of protease and CMCase, respectively were replaced by different inorganic and organic nitrogen sources, one at a time. Results illus- trated in (Figure 4) demonstrated that generally, inorganic nitrogen sources proved less favorable towards enzymes secretion. The same result was previously recorded by Gajju et al. (1996) who found that organic nitrogen sources better suited to Bacillus sp. for enzymes production as organic nitrogen sources being rich in amino acids and short peptides that displayed enzymes production.

The results cited in Figure 4 also showed that the maximum productivity of protease $(63.03 \mathrm{U} / \mathrm{mL})$ and CMCase $(70.07 \mathrm{U} / \mathrm{mL})$ were recorded in the presence of yeast extract and casein, respectively. Yeast extract is an inexpensive organic source of amino acids, proteins and vitamins. It contains abundant nitrogen compounds as well as many growth factors. Casein also contains some essential amino acids as well as some carbohydrates and the inorganic elements calcium and phosphorus.

\section{Salts}

Maximum productivity of protease $(63.14 \mathrm{U} / \mathrm{mL})$ and CMCase $(93.47 \mathrm{U} / \mathrm{mL})$ were recorded in the presence of $0.5 \mathrm{~g} / \mathrm{L}$ of $\mathrm{K}_{2} \mathrm{HPO}_{4}$ and $/$ or $\mathrm{KH}_{2} \mathrm{PO}_{4}$ (Table 1). Beyond this concentration, both enzymes production decreased drastically. The enzymes activity reduced at higher concentrations presumably due to repression of enzymes synthesis. This effect was quite comparable to the result for alkaline protease production by Bacillus firmus in which increased supply of nitrogen and phosphorus stimulated protease synthesis up to certain threshold levels (Moon and Parulekar, 1991). Phosphate plays a vital role as an effector of a large number of enzymatic reactions of primary metabolism, including synthesis of deoxyribonucleic acid and ribonucleic acids (DNA, RNA) and proteins, carbohydrate metabolism, cellular respiration, and control of adenosine triphosphate (ATP) levels.

It is clear from Table 1 that maximum protease $(63.14 \mathrm{U} / \mathrm{mL})$ and CMCase $(93.47 \mathrm{U} / \mathrm{mL})$ were reported when $\mathrm{MgSO}_{4}$ was added in a concentration of 0.1 and $0.4 \mathrm{~g} / \mathrm{L}$, respectively. Any further supplementation had an

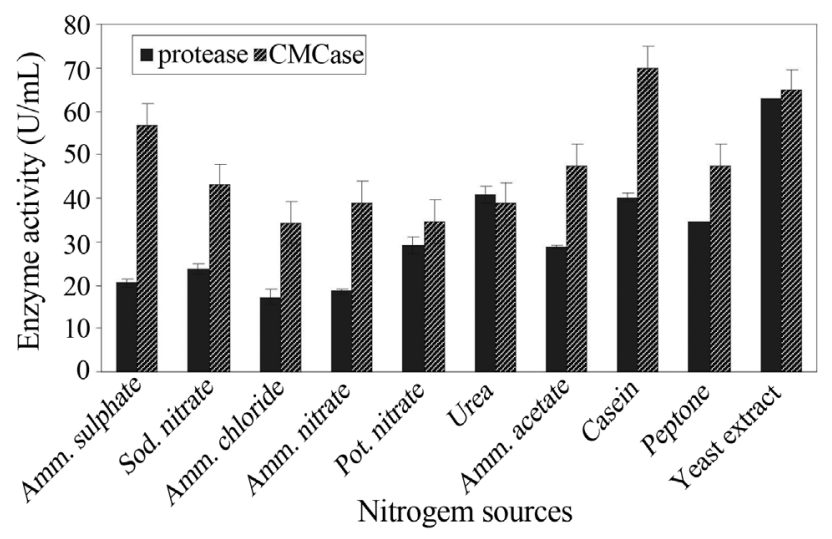

Figure 4 - Effect of different nitrogen sources on the production of protease and CMCase by Bacillus pumilus ATCC 7061. Results are means of three independent determinations. Bars correspond to standard deviation. 
Table 1 - Effect of some salt concentrations on the production of protease and CMCase by Bacillus pumilus ATCC 7061.

\begin{tabular}{lccc}
\hline $\begin{array}{l}\text { Salt conc. } \\
(\mathrm{g} / \mathrm{L})\end{array}$ & $\begin{array}{c}\text { Protease activity } \\
(\mathrm{U} / \mathrm{mL})\end{array}$ & $\begin{array}{c}\text { Salt conc. } \\
(\mathrm{g} / \mathrm{L})\end{array}$ & $\begin{array}{c}\text { CMCase activity } \\
(\mathrm{U} / \mathrm{mL})\end{array}$ \\
\hline & $\mathrm{K}_{2} \mathrm{HPO}$ & \multicolumn{2}{c}{$\mathrm{K}_{2} \mathrm{HPO}_{4} / \mathrm{KH}_{2} \mathrm{PO}_{4}$} \\
$0.00:$ & $53.68 \pm 0.01^{* *}$ & $0: 0:$ & $60.83 \pm 0 * *$ \\
$0.25:$ & $55.44 \pm 0.01^{* *}$ & $0.5: 0.64:$ & $93.47 \pm 0.04^{\mathrm{n}}$ \\
$0.5:$ & $63.14 \pm 0^{* *}$ & $1.0: 1.14:$ & $70.07 \pm 0.01^{* *}$ \\
$1.0:$ & $45.87 \pm 0.03^{*}$ & $1.5: 1.64:$ & $31.57 \pm 0.1^{\mathrm{n}}$ \\
$1.5:$ & $35.75 \pm 0.005^{\mathrm{n}}$ & $2.0: 2.14:$ & $14.63 \pm 0.01^{*}$ \\
\hline & $\mathrm{MgSO}_{4} .7 \mathrm{H}_{2} \mathrm{O}$ & \multicolumn{2}{c}{$\mathrm{MgSO}_{4} .7 \mathrm{H}_{2} \mathrm{O}$} \\
$0.05:$ & $53.68 \pm 0.1^{\mathrm{n}}$ & $0:$ & $42.19 \pm 0.6^{* *}$ \\
$0.1:$ & $63.14 \pm 0.01^{* *}$ & $0.2:$ & $52.97 \pm 0.2^{\mathrm{n}}$ \\
$0.2:$ & $45.87 \pm 0^{* *}$ & $0.4:$ & $93.47 \pm 0.01^{*}$ \\
$0.3:$ & $35.75 \pm 0.02^{*}$ & $0.6:$ & $65.45 \pm 0.01^{*}$ \\
$0.4:$ & $30.00 \pm 0^{*}$ & $0.8:$ & $48.81 \pm 0.02^{*}$ \\
\hline
\end{tabular}

Data represent the mean of 3 different readings \pm standard deviation.

${ }^{\mathrm{n}}=$ Non significant, $\mathrm{p}<0.05 ;{ }^{*}=$ significant, $\mathrm{p} \geq 0.01$ and $\leq 0.05 ; * *=$ highly significant, $\mathrm{p}<0.01$.

inhibitory effect on both enzymes production. This suggested an important role of $\mathrm{Mg}^{+2}$ to increase and stabilized the enzymes production (Paliwal et al., 1994).

\section{Incubation period}

The results represented in Figure 5 show that cell growth and enzymes production increased linearly with increase in incubation time suggesting that enzyme production was growth associated in nature (Johnvesly et al., 2002 ; Ariffin et al., 2006). Maximum growth and enzymes production were recorded after $72 \mathrm{~h}$ of incubation period and this has been reported previously by Heck et al. (2002); Amritkar et al. (2004).

\section{Partial characterization of the produced enzymes}

The description and characterization of the enzymes produced by extremophilic organisms is relevant not only for their participation in the natural cycles in the environment but also for their possible application in industry.

\section{Effect of $\mathrm{pH}$ value on enzymes activity and stability}

Testing the $\mathrm{pH}$-dependence of enzymes activity reveled that both enzymes possessed activities over a broad $\mathrm{pH}$ range (8-12). The results represented in Figures 6 and 7 show that $\mathrm{pH} 10$ was optimum for protease $(63.58 \mathrm{U} / \mathrm{mL})$ and CMCase $(95.32 \mathrm{U} / \mathrm{mL})$ and there was a sharp decrease in activity at $\mathrm{pH}$ 7. This optimum $\mathrm{pH}$ value is identical to that found for endogluconase from Bacillus sp. (Endo et al., 2001).

As the $\mathrm{pH}$ value diverged from the optimum level, the efficient functioning of the enzyme affected and this could be ascribed to decreased saturation of the enzyme with substrate due to a decreased affinity and/or due to the effect of
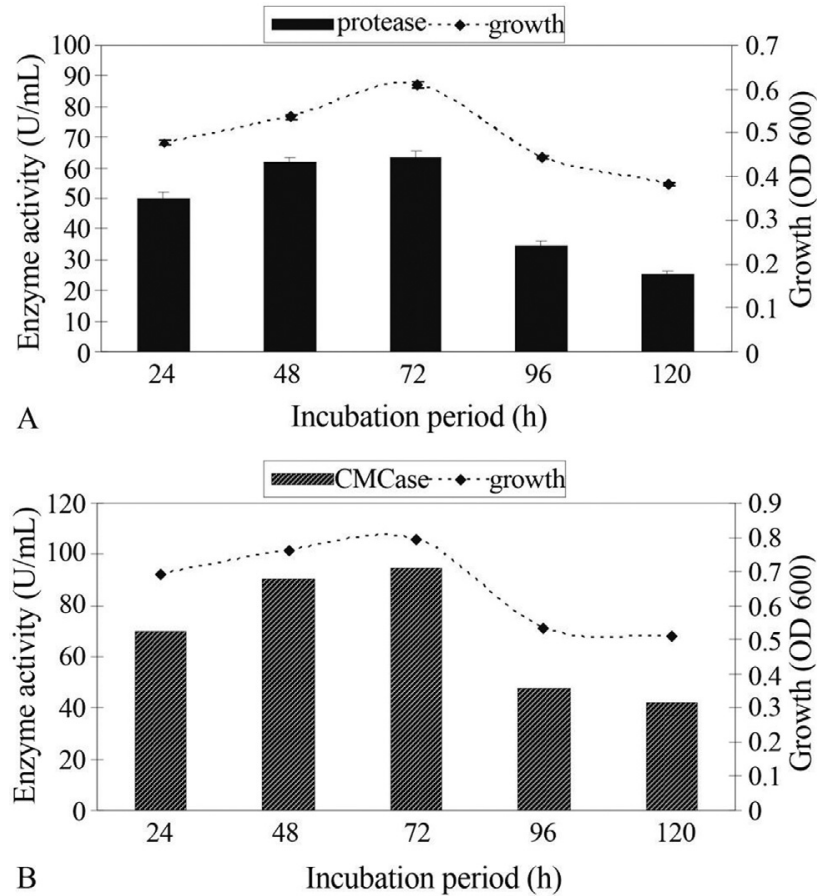

Figure 5 - Effect of different incubation period on growth and the production of protease (A), growth and the production of CMCase (B) by Bacillus pumilus ATCC 7061. Results are means of three independent determinations. Bars correspond to standard deviation.

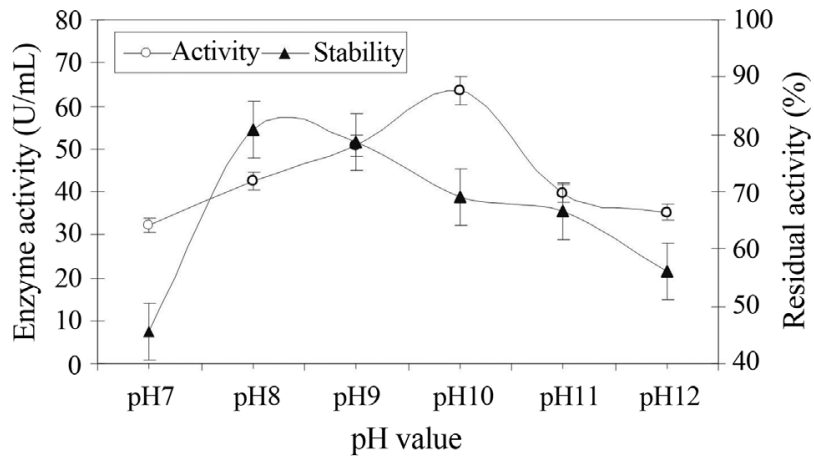

Figure 6 - Activity and stability of the protease produced by Bacillus pumilus ATCC7061 as a function of $\mathrm{pH}$ value. Results are means of three independent determinations. Bars correspond to standard deviation.

pH on the stability of the enzyme (Dixon and Webb, 1979). In this study, testing $\mathrm{pH}$ stability of the protease and CMCase produced by Bacillus pumilus ATCC7061 revealed that maximum stability of protease and CMCase enzymes were observed at $\mathrm{pH} 8$ and $\mathrm{pH} 9$, they retained 80.79 and $93.21 \%$ of their original activities, respectively after incubation of the enzymes for one hour at $40{ }^{\circ} \mathrm{C}$ within this $\mathrm{pH}$ range (Figures 6 and 7). Taking into account such considerations and the well known fact that many industrial processes are operated at $\mathrm{pH}$ extremes (either acidic or alkaline) therefore, the industrially important enzymes must be capable of withstanding such harsh and hostile condi- 


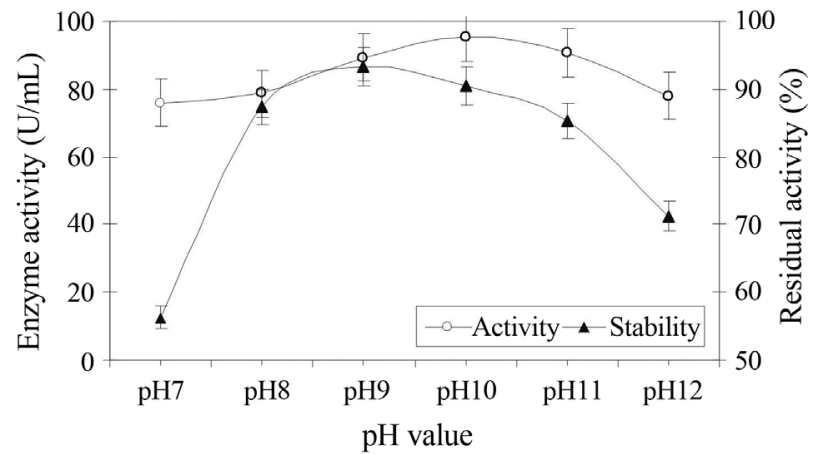

Figure 7 - Activity and stability of the CMCase produced by Bacillus pumilus ATCC7061 as a function of $\mathrm{pH}$ value. Results are means of three independent determinations. Bars correspond to standard deviation.

tions for prolonged periods or at least during the process time.

\section{Effect of temperature on enzymes activity and stability}

Temperature is a critical factor for maximum enzyme activity and it is a prerequisite for industrial enzymes to be active and stable at higher temperature. Results cited in Figures 8 and 9 show that optimum activities were recorded at $50{ }^{\circ} \mathrm{C}(64.90$ and $106.10 \mathrm{U} / \mathrm{mL})$ for protease and CMCase, respectively. The activities reduced to

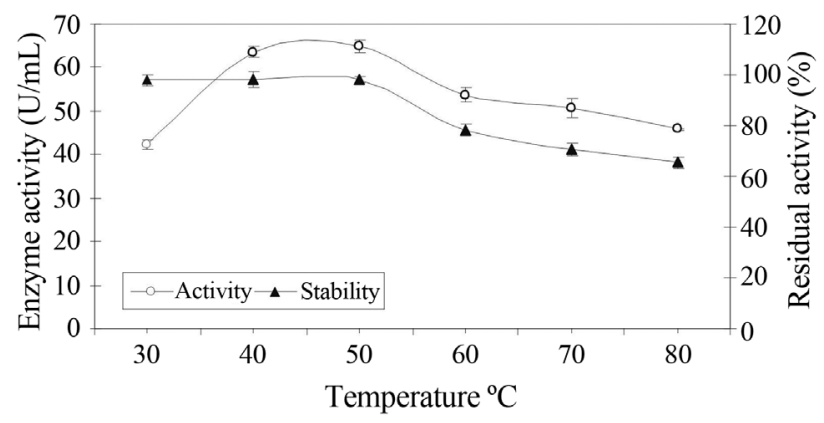

Figure 8 - Thermal activity and stability of the protease produced by $B a$ cillus pumilus ATCC 7061. Results are means of three independent determinations. Bars correspond to standard deviation.

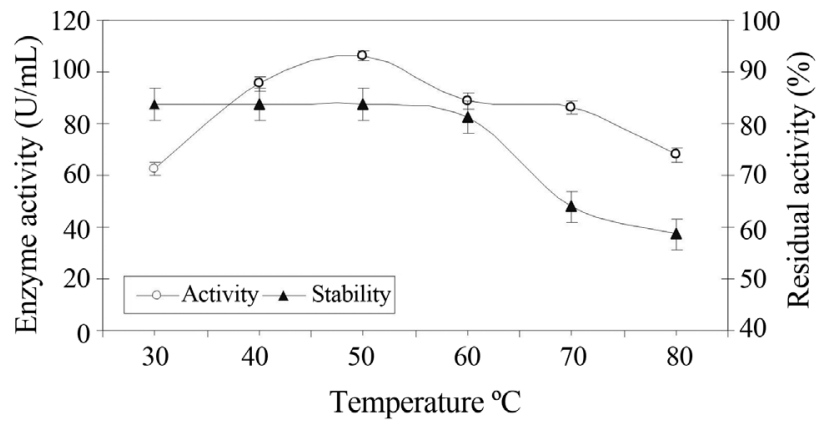

Figure 9 - Thermal activity and stability of CMCase produced by Bacillus pumilus ATCC 7061. Results are means of three independent determinations. Bars correspond to standard deviation.
$50.60(\mathrm{U} / \mathrm{mL})$ for protease and $86.24(\mathrm{U} / \mathrm{mL})$ for CMCase at $70{ }^{\circ} \mathrm{C}$. The enzymes were completely inactivated at $80^{\circ} \mathrm{C}$. Similarly Kumar (2002) found maximum activity of protease produced by B. pumilus was at $50-55^{\circ} \mathrm{C}$.

For analysis of thermal stability, enzymes were incubated for $1 \mathrm{~h}$ in glycine-NaOH buffer ( $\mathrm{pH}$ 10.0) at different temperatures $\left(30-80^{\circ} \mathrm{C}\right)$. The results illustrated in Figures 8 and 9 revealed that both enzymes showed good activities over a temperature range of $30-60{ }^{\circ} \mathrm{C}$. However, the enzymes were rapidly inactivated and retained only 70.67 and $64.00 \%$ for protease and CMCase, respectively after $1 \mathrm{~h} \mathrm{in-}$ cubation at $70{ }^{\circ} \mathrm{C}$. There were sharp decreases in the enzymes activity with further increase in temperature due to the denaturation of the enzyme proteins (Dixon and Webb, 1979).

These findings suggest that the protease and CMCase secreted by Bacillus pumilus ATCC7061 have highly and stable alkaline properties with moderate heat stability which indicated to be good additives for enzyme-based detergent applications as they can withstand and work at elevated $\mathrm{pH}$ and temperatures during process conditions (Bischoff et al., 2006).

\section{Effect of some metals ions, surfactants and inhibitors on enzymes activity}

Effect of some metals ions, surfactants and some inhibitors on activity of protease and CMCase were investigated and the data are presented in Table 2. While $\mathrm{Hg}^{2+}$, $\mathrm{Fe}^{2+}$ and $\mathrm{Ag}^{+}$enhanced protease activity slightly, metals caused enhancement of CMCase were $\mathrm{Fe}^{2+}, \mathrm{Mg}^{2+}, \mathrm{Ca}^{2+}$, $\mathrm{Cu}^{2+}$ and $\mathrm{Ag}^{+}$. Paliwal et al. (1994) previously stated that the metal ions apparently protected the enzymes against thermal denaturation and played a key role to continue the active conformation of the enzymes at high temperatures. Moreover, Mansfield et al. (1998) suggested that $\mathrm{Ca}^{2+}$ ions have been reported to be required for enhancing the substrate binding affinity of the enzyme and stabilizing the conformation of the catalytic site.

While Kumar (2002) reported that B. pumilus alkaline protease lost $22 \%$ activity on treatment with $0.1 \%$ SDS for $1 \mathrm{~h}$. Protease and CMCase enzymes from Bacillus pumilius were stable not only towards the nonionic surfactants like Triton X-100 and Tween 80 but also the strong anionic surfactant, SDS. Moreover, the enzymes were not significantly inhibited with the specific inhibitor EDTA or with cystein. They retained $88-95 \%$ of their activities by adding these inhibitors, suggesting that metal cofactors are not required for enzymes activities. This property of the enzymes was very useful for application as detergent additive (Beg and Gupta, 2003). These results were in accordance with Aygan and Arikan (2008) who reported that the endoglucanase enzyme produced by Bacillus sp. C14 was resistant to chelating agent EDTA and SDS by preserving original enzyme activity around 93 and $81 \%$, respectively. 
Table 2 - Effect of different metals ions, surfactants and inhibitors on the activity of alkaline protease and CMCase enzymes by Bacillus pumilus ATCC 7061.

\begin{tabular}{lcc}
\hline \multirow{2}{*}{$\begin{array}{l}\text { Metals ions, surfactants } \\
\text { and inhibitors }\end{array}$} & \multicolumn{2}{c}{ Relative activity (\%) } \\
\cline { 2 - 3 } Control (no addition) & 100 & CMCase \\
$\mathrm{NaCl}$ & $98.8 \pm 5.39^{* *}$ & $93.7 \pm 3.20^{* *}$ \\
$\mathrm{KCl}$ & $96.1 \pm 2.62^{\mathrm{n}}$ & $85.3 \pm 2.07^{* *}$ \\
$\mathrm{AgNO}_{3}$ & $102.5 \pm 2.01^{\mathrm{n}}$ & $103.4 \pm 5.54^{* *}$ \\
$\mathrm{MgCl}_{2}$ & $87.9 \pm 0.32^{* *}$ & $102.6 \pm 2.00^{* *}$ \\
$\mathrm{CaCl}_{2}$ & $95.2 \pm 2.14^{* *}$ & $102.1 \pm 4.30^{*}$ \\
$\mathrm{CuSO}_{4}$ & $94.7 \pm 6.46^{*}$ & $109.2 \pm 0^{* *}$ \\
$\mathrm{ZnSO}_{4}$ & $98.8 \pm 4.08^{\mathrm{n}}$ & $87.9 \pm 1.53^{* *}$ \\
$\mathrm{FeSO}_{4}$ & $105.5 \pm 3.16^{* *}$ & $125.2 \pm 3.25^{\mathrm{n}}$ \\
$\mathrm{HgI}_{2}$ & $102.2 \pm 1.45^{* *}$ & $88.96 \pm 1.66^{* *}$ \\
$\mathrm{SDS}$ & $92.03 \pm 2.62^{\mathrm{n}}$ & $93.3 \pm 2.00^{* *}$ \\
$\mathrm{Triton}_{\mathrm{T}-100}$ & $95.9 \pm 5.13^{* *}$ & $82.4 \pm 3.00^{*}$ \\
$\mathrm{Tween}_{0}$ & $89.1 \pm 1.48^{*}$ & $94.9 \pm 1.38^{*}$ \\
$\mathrm{EDTA}$ & $92.03 \pm 2.48^{* *}$ & $91.1 \pm 0.21^{\mathrm{n}}$ \\
$\mathrm{L}-\mathrm{cystein}$ & $95.9 \pm 0.07^{* *}$ & $88.67 \pm 0.07$ \\
\hline
\end{tabular}

Data represent the mean of 3 different readings \pm standard deviation.

${ }^{\mathrm{n}}=$ Non significant, $\mathrm{p}<0.05 ;{ }^{*}=$ significant, $\mathrm{p} \geq 0.01$ and $\leq 0.05 ; * *=$ highly significant, $\mathrm{p}<0.01$.

\section{Compatibility with Detergents}

Enzymes activity and stability in presence of some available commercial detergents was studied with a view to exploit the enzymes in detergent industry. Protease maintained $78.81,97.9,94.06$ and $92.71 \%$ of residual activity in Aerial, Tide, Persil and Xtra, respectively, after $1 \mathrm{~h}$ incubation, at $50{ }^{\circ} \mathrm{C}$. Whereas, $\mathrm{CMCase}$ retained $78.66,72.13$, 56.02 and $51.81 \%$ in the mentioned detergents (Figure 10). CMCase produced by an alkalithermophillic actinomycete kept a residual activity of 85,72 and $66 \%$ when tested with the detergents (George et al., 2001). Also, Madan et al. (2002) studied the compatibility of alkaline protease from

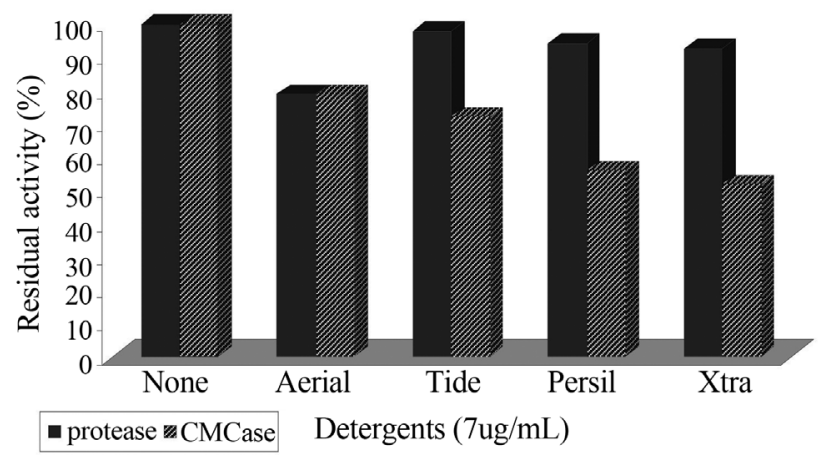

Figure 10 - Compatibility of alkaline protease and CMCase activities from $B$. pumilus ATCC7061 with commercial detergents.
Bacillus polymyxa, it retained $20-84.5 \%$ of its activity in various detergents. Comparing these results, the alkaline protease and CMCase produced by B. pumilus ATCC7061 were significantly more stable in commercial detergents.

\section{Application of protease and CMCase}

An application for protease enzyme was degradation of human hair. The present results showed that the human hair degraded by $50 \%$. It was appeared to be potentially useful in washing powder. Alkaline protease speeds up the process of dehairing, because the alkaline conditions enabled the swelling of hair follicle protein and allowed easy removal of the hair. Horikoshi (1999) reported that alkaline enzymes had been used in the hide dehairing process, where dehairing was carried out at $\mathrm{pH}$ values between 8 and 10. Proteases are used for selective hydrolysis of nonfibrillar proteins of the skin and for removal of non fibrillar proteins such as albumins and globulins. The purpose of soaking is to swell the hide, and this step was performed with alkali (Godfrey and West, 1996). In addition, an application of CMCase was degradation of cotton fibers. The experiment conducted aiming at the application in textile industry, measuring the loss of weigh of a cotton fabric. CMCase had shown a loss of weight by $40 \%$. This can indicate a possible application of CMCase from B. pumilus in stonewashing and biopolishing.

\section{References}

Amritkar N, Kamat M, Lali A (2004) Expanded bed affinity purification of bacterial $\alpha$-amylase and cellulose on composite substrate analogue-cellulose matrices. Process Biochem 39:565-570.

Ariffin H, Abdullah N, Umi Kalsom MS, Shirai Y, Hassan MA (2006) Production and characterization of cellulase by $\mathrm{Ba}$ cillus pumilus EB3. Int J Eng Technol 3:47-53.

Aygan A, Arikan B (2008) A new halo-alkaliphillic thermostable endoglucanase from moderately halophilic Bacillus spC14 isolated from van soda lake. Int J Agri Biol 10:369-374.

Beg QK, Gupta R (2003) Purification and characterization of an oxidationstable thiol-dependent serine alkaline protease from Bacillus mojavensis. Enz Microb Technol 32: 294-304.

Bischoff KM, Rooney AP, Li XL, Liu S, Hughes SR (2006) Purification and characterization of a family 5 endoglucanase from a moderately thermophillic strain of Bacillus licheniformis. Biotechnol Lett 28:1761-1765.

Denizci AA, Kazan D, Abeln EC, Erarslan A (2004) Newly isolated Bacillus clausii GMBAE 42: an alkaline protease producer capable to grow under highly alkaline conditions. J Appl Microbiol 96:320-327.

Dixon M, Webb EC (1979) Enzyme kinetics In: Enzymes 3rd edition Academic Press New York San Francisco. A subsidiary of Harcourt Brace Jovanovich Publishers Longman Group p 47.

Ellaiah P, Adinarayana K, Pardasaradhi SV, Srinivasulu B (2002a) Isolation of alkaline protease producing bacteria from Visakha-patnam soil. Ind J Microbiol 42:173-175. 
Ellaiah P, Srinivasulu B, Adinarayana K (2002b) A review on microbial alkaline proteases. J Sci Ind Res 61:690-704.

Endo K, Hakamada Y, Takizawa S, Kubota H (2001) A novel alkaline endoglucanase from an alkaliphillic Bacillus isolate: enzymatic properties and nucleotide and deduced amino acid sequences. Appl Microbiol Biotechnol 57:109-116.

Gajju H, Bhalla TC, Agarwal HO (1996) Thermostable alkaline protease from thermophilic Bacillus coagulans $\mathrm{PB}-77$. Ind $\mathrm{J}$ Microbiol 36:153-155.

George SP, Ahmad A, Rao MB (2001) Studies on carboxymethyl cellulase produced by an alkalithermophillic actinomycete. Bioresour Technol 77:171-175.

Godfrey T, West S (1996) Industrial enzymology 2nd ed Macmillan Publishers Inc New York NY.

Grant WD, Jones BE (2000) Alkaline environments. In: Lederberg J (ed) Encyclopaedia of Microbiology, 2nd ed. Academic Press New York 1 p126-133.

Gupta R, Beg QK, Lorenz P (2002) Bacterial alkaline proteases: molecular approaches and industrial application. Appl Microbial Biotechnol. 59:15-32

Heck JX, Hertz PF, Ayub MAZ (2002) Cellulose and xylanase production by isolated amazon Bacillus strains using soybean industrial residue based solid-state cultivation Brazilian J Microbiol 33:213-218.

Horikoshi K (1990) Enzymes of alkaliphiles. In: Fogarty WM, Kelly CT (eds) Microbial Enzymes and Biotechnology pp 275-294.

Horikoshi K (1991) Microorganisms in Alkaline Environments VCH New York.

Horikoshi K (1999) Alkaliphiles: some applications of their products for biotechnology. Microbiol Mol Biol Rev 63:735750 .

Johnvesly B, Naik GR (2001) Studies on production of thermostable alkaline protease from thermophilic and alkaliphillic Bacillus sp JB-99 in a chemically defined medium. Process Biochem 37:139-144.

Johnvesly B, Manjunath BR, Naik GR (2002) Pigeon pea waste as a novel inexpensive substrate for production of a thermostable alkaline protease from thermo-alkaliphillic Bacillus sp JB-99. Bioresour Technol 82:61-64.

Jones BE, Grant WD, Duckworth AW, Owenson GG (1998) Microbial diversity of soda lakes. Extrem 2:191-200

Joo HS, Kumar CG, Park GC, Paik SR, Chang CS (2003) Oxidant and SDS stable alkaline protease from Bacillus clausii I-52: production and some properties. J Appl Microbiol 95:267272.

Kitajima J, KimizukaK (1998) Constituents of Ficus pumila leaves. Chem Pharm Bull Tokyo 46:1647-1649.
Kumar CG (2002) Purification and characterization of thermostable alkaline protease from alkaliphillic Bacillus pumilus . Lett Appl Microbiol 34:13-17.

Lee YJ, Kim BK, Lee BH, Jo KI, Lee NK (2006) Purification and characterization of cellulase produced by Bacillus amyoliquefaciens DL-3 utilizing rice hull. Coll Nat Res Life Sci 840:604-714.

Lo HF, Lin LL, Chen HL, Hsu HH, Chang CT (2001) Enzymatic properties of a SDS-resistant Bacillus sp TS-23 a-amylase produced by recombinant $E$ coli. Process Biochem 36:743750 .

Lowry OH, Rosebrough N, Farr AL, Randall RJ (1951) Protein measurement with Folin phenol reagent. J Biol Chem 193:265-275.

Madan M, Dhillon S, Singh R (2002) Production of alkaline protease by a UV mutant of Bacillus polymyxa. Ind J Microbiol 42:155-159.

Mansfield SD, Saddler JN, Gubitz GM (1998) Characterisation of endoglucanases from the brown rot fungi Gloeophyllum sepiarium and Gloeophyllum traberum. Enzyme Microb Biotechnol 23:133-140.

Moon SH, Parulekar SJ (1991) A parametric study of protein production in batch and fed-batch culture of Bacillus firmus. Biotechnol Bioeng 37:467-483.

Nizamudeen S, Bajaj B K (2009) A novel thermo-alkalitolerant endoglucanase production using cost-effective agricultural residues as substrates by a newly isolated Bacillus sp NZ. Food Technol Biotechnol 47:435-440.

Paliwal N, Singh SP, Garg SK (1994) Cation induced thermal stability of an alkaline protease from a Bacillus sp. Bioresour Technol 50:209-211.

Silva DR, Lago ES, Merheb CW, Macchione MM, Park YK, Gomes E (2005) Production of xylanase and CMCase on solid fermentation in different residues by Thermoascus aurantiacus miehe. Braz JMicrobiol 36:235-241.

Tarek AAM, Nagwa AT (2007) Optimization of cellulase and glucosidase induction by sugarbeet pathogen Sclerotium rolfsii. Afr J Biotechnol 6:1048-1054.

Ul-Qadar SA, Shireen E, Iqbal S, Anwar A (2009) Optimization of protease production from newly isolated strain of Bacillus sp PCSIR EA-3. Ind J Biotechnol 8:286-290.

Wood TM, Bhat KM (1998) Method for measuring cellulase activities In: Wood WA Kellogg JA (eds) Methods in enzymology cellulose and hemicellulose. Academic Press New York 160 p.87-112.

Yang JK, Shih IL, Tzeng YM, Wang SL (2000) Production and purification of protease from a Bacillus subtilis that can deproteinize crustacean wastes. Enzyme Microb Technol 26:406-413.

All the content of the journal, except where otherwise noted, is licensed under a Creative Commons License CC BY-NC. 